\title{
Notes on the ecology and physiology of the Antarctic oribatid mite Maudheimia wilsoni*
}

\author{
LAURITZ SøMME, ALEXANDER STRøMME and KARL ERIK ZACHARIASSEN
}

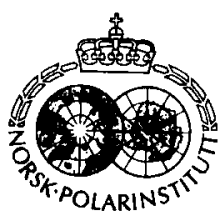

\begin{abstract}
Sømme, L., Strømme, A. \& Zachariassen, K. E. 1993: Notes on the ecology and physiology of the Antarctic mite Maudheimia wilsoni. Polar Research 12(1), 21-25.

The oribatid mite Maudheimia wilsoni Dalenius was found to be numerous on the underside of stones at Jutulsessen $\left(72^{\circ} \mathrm{S}, 3^{\circ} \mathrm{E}\right)$ in Dronning Maud Land, Antarctica. Daily temperature fluctuations of the microhabitat from as high as $19^{\circ} \mathrm{C}$ and to as low as $-17^{\circ} \mathrm{C}$ were observed during the austral summer. Optimal activity of the mites occurred at $10^{\circ} \mathrm{C}$. Even in January the mean supercooling point of adult mites was as low as $-30.8 \pm 4.7^{\circ} \mathrm{C}$. Haemolymph osmolality ranged from 500 to $800 \mathrm{mOsmol}$ and thermal hystersis freezing points from -4.7 to $-6.1^{\circ} \mathrm{C}$. Adult mites had a mean water content of $43.6 \%$ and a water loss rate of $0.12 \mu \mathrm{g} \mathrm{h}^{-1}$ at $15^{\circ} \mathrm{C}$ and $10 \%$ relative humidity.
\end{abstract}

Lauritz Sømme, Institute of Biology, University of Oslo, P.O. Box 1050 Blindern, N-0316 Oslo, Norway; Alex Strømme, Department of Ecotoxicology, ALLFORSK, N-7055 Draguoll, Norway; Karl Erik Zachariassen, Institute of Zoology, University of Trondheim, N-7055 Dragvoll, Norway.

\section{Introduction}

Only three species of orabatid mites have been recorded from the Antarctic Continent. Maudheimia petrovia Wallwork has been reported from north Victoria Land only, while Alaskozetes antarcticus (Michael) is also widely distributed in the Maritime and subantarctic zones (Wallwork 1967). Maudheimia wilsoni Dalenius is endemic to western Dronning Maud Land (Sømme 1986a; Ryan \& Watkins 1989). While $A$. antarcticus has been the subject of numerous ecological and physiological studies (Block 1984; Sømme \& Block 1991), very little is known about $M$. wilsoni. High densities of this species, however, have been reported from the Robertskollen group of nunataks (Ryan \& Watkins 1989), and the mite was observed to be common in the Jutulsessen area, Gjelsvikfjella, Dronning Maud Land, by one of the present authors (A.S.).

The purpose of the present study was to investigate the ecology and physiology of $M$. wilsoni in the Jutulsessen area, especially with respect to local distribution, life-cycle and adaptations to the Antarctic environment.

\section{Material and methods}

The investigation was carried out during the

\footnotetext{
* Publication No. 114 of the Norwegian Antarctic Research Expeditions 1976/77, 1978/79, 1984/85 and 1989/90.
}

Norwegian Antarctic Research Expedition (NARE) 1989/90 from 13 January to 15 February 1990. The mites were collected in the vicinity of the Norwegian field station "Troll" $\left(72^{\circ} 0.7\right.$ 'S, $2^{\circ} 32.3^{\prime} \mathrm{E}$ ) (Norsk Polarinstitutt 1990) in Jutulsessen. A survey of the botany of the area has been presented by Engelskjøn (1986).

The mites were sampled by means of a small aspirator and kept in $5 \mathrm{ml}$ glass vials at temperatures ranging from 0 to $-10^{\circ} \mathrm{C}$. They were used in the experiments within 48 hours after sampling.

Adults were separated from larvae and the nymphal stages in the field. Adult specimens only were used for the present study, without separation of the sexes.

Temperature recordings were carried out with a Grant Squirrel 1200 data logger. Supercooling points (SCPs) were measured by attaching 5-7 mites to a copper-constantan thermocouple by means of vaseline. The thermocouple was placed inside three plastic tubes, one outside the other, and lowered into a cold mixture made from crushed ice and $\mathrm{CaCl}_{2} \cdot 6 \mathrm{H}_{2} \mathrm{O}$. SCPs were registered for 30 specimens at a cooling rate of approximately $1^{\circ} \mathrm{C} \mathrm{min}{ }^{-1}$.

Haemolymph osmolality and thermal hysteresis activity were measured in a Clifton nanoliter osmometer as described by Aunaas et al. (1983). Some modifications of the procedure had to be made due to the small volumes of haemolymph that could be extracted from the mites. Each mite 
was embedded in a drop of liquid paraffin on a cover glass slide. Subsequently, the mite was punctured with a needle and droplets of haemolymph were pulled out in the paraffin. The cover glass was placed on the Peltier cell of the osmometer, and the melting and freezing of the droplets observed under a binocular microscope.

In order to study the nutrition of the mites, the presence of microphyte flora in their surroundings was investigated. Incrustations and coatings were scraped off from the stones and brought to Oslo for closer examination.

The activities of the mites at different temperatures were studied by placing individual specimens at the bottom of glass capillary tubes which had been closed in one end. A thermocouple was put into a similar capillary, and both capillaries were placed in a fixed position with their closed ends in a vial filled with water. The water served as a thermal buffer. The activity of the mites was studied at different temperatures and judged on a subjective scale. Zero corresponded to no movements during a period of 30 seconds, 1 to small movements, 2 moderate movements, and 3 to quick movements of the legs.

\section{Results}

\section{Occurrence of the mites}

The main distribution of the $M$, wilsoni appeared to be restricted to Grjotlia in the outer NW part of the Jutulsessen mountain complex, but scattered specimens were found over the entire area, including the inner slopes of Jutulsessen.

The area is generally dry. During the expedition period precipitation was rarely observed, but drifting snow occasionally covered the ground for hours. The melting of this snow and melting of ice and larger deposits of snow from higher elevations are the only sources of ground humidity.

The mites were found under rocks of different geological origin, shapes and sizes. They appeared, however, to prefer pelitic gneisses (Yoshihide Ohta, pers. comm.) with the approximate dimensions of $1 \times 15 \times 3 \mathrm{~cm}$. The substratum under the stones was mainly composed of relatively dry sand and gravel.

The mites were found both as single individuals and in aggregations with up to 30 specimens. They appeared to be quite stationary on the underside

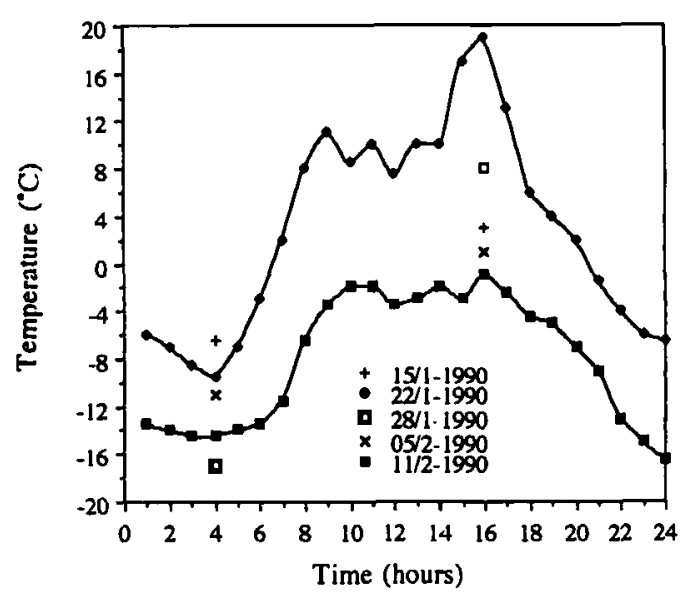

Fig. 1. Temperature recordings from typical microhabitat for Maudheimia wilsoni through 24 hours on 22 January and 5 February 1990 (filled symbols) and 4 a.m. and 4 p.m. on three additional days.

of the stones. Single mites were always adults, while the aggregations consisted of juveniles and adults. Old cuticular cast-offs from nymphs were frequently observed in the aggregations.

The air temperatures in the area varied between 6 and $-22^{\circ} \mathrm{C}$ (Winther 1990), but temperatures in the microhabitats of the mites could be considerably higher. Examples of dial temperature fluctuations are presented in Fig. 1. During the expedition period this microhabitat was exposed to the sun for 10-12 hours. The highest observed temperature in the middle of January was $19^{\circ} \mathrm{C}$, but temperatures remained below $0^{\circ} \mathrm{C}$ for half of the day. In the middle of February temperatures did not exceed $0^{\circ} \mathrm{C}$ even during the warmest part of the day, which occurred around 4 p.m.

\section{Nutrition}

The only visible plants in the area were different species of crustose lichens on rocks and stones, as well as scattered occurrences of the green alga Prasiola on moist gravel. No macrophytes were observed under the stones. Cultivation of organisms from different substrates in the Jutulsessen area revealed rich occurrences of diatomers, coccoide bacteria, protozoans, rotifers and 17 species of algae (Olav Skulberg, pers. comm.), some of which may be potential sources of nutrition for the mites. No growth of any organisms was observed from substratum collected close to the mites. 


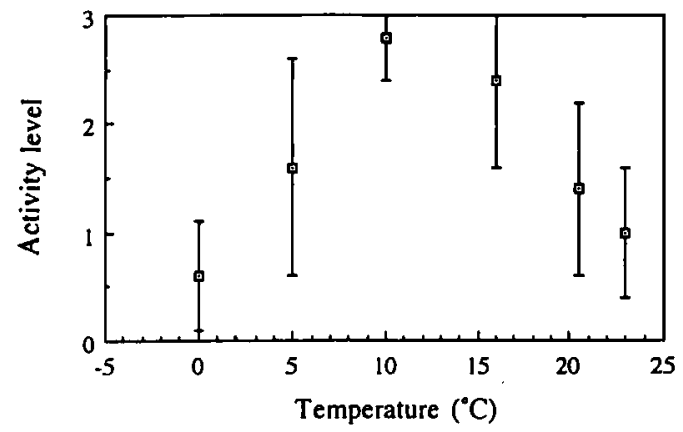

Fig. 2. Levels of activity of adult Maudheimia wilsoni at different temperatures. Mean $( \pm S D)$ are presented $(n=5)$. See text for further explanation.

\section{Levels of activity}

The activity levels of the mites at different temperatures are presented in Fig. 2. Their activity was very low at $0^{\circ} \mathrm{C}$, while a maximum level was reached at $10^{\circ} \mathrm{C}$. At temperatures above $15^{\circ} \mathrm{C}$ the activity was greatly reduced. This pattern is in correspondence with the actual temperatures of their microhabitats (Fig. 1).

\section{Water balance}

The relative water content and the water loss rate were determined in eight specimens of $M$. wilsoni (Table 1 ). At $15^{\circ} \mathrm{C}$ and $10 \%$ relative humidity a water loss rate of $0.44 \% \mathrm{~h}^{-1}$ was observed. The mites had a low water content of only $43.6 \%$.

\section{Cold hardiness}

The supercooling points of 30 adult mites had a mean $( \pm \mathrm{SD})$ of $-30.8 \pm 4.7^{\circ} \mathrm{C}$ (Table 2). For summer acclimated arthropods this is a very low level.

As shown in Table 2 the haemolymph osmolality of five adult mites had a mean value of $694 \mathrm{mOsmol}$, corresponding to a melting point of $-1.3^{\circ} \mathrm{C}$. Determination of the hysteresis freezing point was possible only in two specimens, which showed values as low as -4.7 and $-6.1^{\circ} \mathrm{C}$.

\section{Discussion}

The nunataks of the Antarctic Continent offer some of the most hostile environments on earth. Winter conditions prevail for almost ten months and winter temperatures in the range of -40 to $-50^{\circ} \mathrm{C}$ may be expected. Studies on the collembolan Cryptopygus sverdrupi from Dronning Maud Land (Sømme 1986b) showed that the temperatures of their microhabitats may drop below $-10^{\circ} \mathrm{C}$ when they are in the shade. Thus, temperatures may be too low for growth and development during part of the day even in midsummer. Similar observations were made during the present study, and the low supercooling points of summer-acclimated $M$. wilsoni are important for survival under such conditions.

Thermal hysteresis agents are usually found in insects hibernating in sites where they become exposed to severe cold. The agents are assumed to protect the insects against spontaneous ice nucleation and against inoculation of external ice through the body wall (Zachariassen \& Husby 1982). The presence of thermal hysteresis factors in the body fluids of the mites is likely to reflect the cold temperatures that prevail in the Antarctic Continent even during the summer. It also sug-

Table 1. Initial fresh weight of eight adult specimens of $M$. wilsoni, weight after 40 hours and mean rate of water loss at $10^{\circ} \mathrm{C}$ and $10 \%$ r.h. Dry weight after drying at $80^{\circ} \mathrm{C}$ and relative water content are also presented.

\begin{tabular}{lllll}
\hline $\begin{array}{l}\text { Fresh weight }(\mu \mathrm{g}) \\
\overline{\mathrm{x}} \pm \mathrm{SD}\end{array}$ & $\begin{array}{l}\text { Weigh after } \\
40 \mathrm{~h} \text { at } 15^{\circ} \mathrm{C}\end{array}$ & $\begin{array}{l}\text { Rate of water loss } \\
(\mu \mathrm{g} / \mathrm{h})\end{array}$ & $\begin{array}{l}\text { Dry weight } \\
(\overline{\mathrm{x}} \pm \mathrm{SD})\end{array}$ & $\begin{array}{l}\text { Water content } \\
\%(\overline{\mathrm{x}} \pm \mathrm{SD})\end{array}$ \\
\hline $27.2 \pm 2.2$ & $22.4 \pm 3.1$ & 0.12 & $15.2 \pm 1.3$ & $43.6 \pm 5.7$ \\
\hline
\end{tabular}

Table 2. Supercooling points, haemolymph osmolality and thermal hysteresis freezing points of adult $M$. wilsoni.

\begin{tabular}{|c|c|c|}
\hline $\begin{array}{l}\mathrm{SCP}\left({ }^{\circ} \mathrm{C}\right) \\
n \quad \overline{\mathrm{x}} \pm \mathrm{SD}\end{array}$ & $\begin{array}{l}\text { Osmolality (mOsmol) } \\
n \quad \bar{x} \pm \text { SD }\end{array}$ & $\begin{array}{l}\text { Hyst. freez. pt. }\left({ }^{\circ} \mathrm{C}\right) \\
\mathrm{n} \text { range }\end{array}$ \\
\hline $30-30.8 \pm 4.7$ & $5 \quad 694 \pm 125$ & $2-4.7 /-6.1$ \\
\hline
\end{tabular}


gests that the microhabitat of the mites is frozen so that inoculative freezing would occur if not prevented by the thermal hysteresis freezing point.

The relatively low osmolality values indicate that the body fluids of the mites do not contain high levels of polyols. This is in agreement with the idea that accumulation of polyols is incompatible with the metabolic requirements of the active state. Even winter-active insects, which are active in a supercooled state at temperatures only slightly above the supercooling point, do not display accumulated polyols (Husby \& Zachariassen 1979). Since the mites of the present investigation are likely to have been feeding and reproducing at the time when the measurements were made, they probably possess an active metabolic system incompatible with high polyol accumulation.

The physiological function of polyols in freezesensitive insects is to increase the supercooling capacity, so that the insects can experience lower temperatures without undergoing lethal freezing (e.g. Sømme 1982; Zachariassen 1985). Insects without polyols will usually supercool to only about $-20^{\circ} \mathrm{C}$. In spite of the absence of accumulated polyols, the mites of the present study are able to supercool to about $-30^{\circ} \mathrm{C}$. The relatively low supercooling points of the mites are probably due to their small body size, which will depress the supercooling points by a volume effect (Bigg 1953). According to Bigg (1953), there is a logarithmic relation between the sample volume of water and the SCP, and reduction of water volume by one logarithmic unit is associated with a supercooling point depression of about $2.5^{\circ} \mathrm{C}$. While insects which supercool to $-20^{\circ} \mathrm{C}$ have an average body mass of about $150 \mathrm{mg}$, the mites of the present study have a body mass of about $28 \mu \mathrm{g}$, i.e. the body masses deviate by a factor of about 5,500 , corresponding to 3.74 logarithmic units. According to the data of Bigg (1953) this deviation would imply a volume-induced difference in supercooling points of more than $10^{\circ} \mathrm{C}$, which corresponds well to the difference between the supercooling points of the relatively large insects and the relatively small mites.

Active alpine insects which are exposed to moderately low temperatures at night are often tolerant to freezing. However, since these insects usually lack accumulated polyols, they tolerate freezing to only about $-7^{\circ} \mathrm{C}$ (van der Laak 1982; Sømme \& Zachariassen 1981). Active insects which are exposed to substantially lower tem- peratures must rely on other cold hardening mechanisms than polyol accumulation. Freezeavoidance by means of a reduction in body size might be considered as an alternative cold hardening strategy.

At Robertskollen, Ryan \& Watkins (1989) found that $M$. wilsoni is concentrated on the underside of stones, but appears to prefer areas with large amounts of fruticose lichens. Since the Robertskollen group of nunataks is situated at an elevation of only $200-500 \mathrm{~m}$, they probably have a richer vegetation than the slopes at Jutulsessen. Both in their study and in the present investigation the mites appeared to feed on microorganisms. Further studies on the nutrition of the mites should be carried out to understand the ecology of this species, in particular since a diet free of nucleating agents may be essential for maintaining the species' high supercooling capacity during the summer.

Acknowledgements. - The present study was carried out with the support of the Norwegian Antarctic Research Expedition (NARE) 1989/90. We would like to thank O. Skulberg for identification of microphytes from Jutulsessen.

\section{References}

Aunaas, T., Baust, J. G. \& Zachariassen, K. E. 1983: Ecophysiological studies on arthropods from Spitsbergen. Polar Res. 1 n.s., 235-240.

Bigg, K. E. 1953: The supercooling of water. Proc. Phys. Soc. Lond. B66, 688-694.

Block, W. 1984: Terrestrial microbiology, invertebrates and ecosystems. Pp. 162-236 in Laws, R. M. (ed.): Antarctic Ecology, Vol. 1. Academic Press, London.

Engelskjøn, T. 1986: Botany of two Antarctic mountain ranges: Gjelsvikfjella and Mühlig-Hofmannfjella, Dronning Maud Land. I. General ecology and development of the Antarctic cold desert cryptogam formation. Polar Res. 4 n.s., 205-224.

Husby, J. A. \& Zachariassen, K. E. 1979: Antifreeze agents in the body fluid of winter active insects and spiders. Experientia $36,963-964$.

Norsk Polarinstitutt 1990: Establishment of Troll, a new station facility for summer operations. Norsk Polarinst. Rapp. 65. 26 pp.

Ryan, P. G. \& Watkins, B. P. 1989: The influence of physical factors and ornithogenic products on plant and arthropod abundance at an inland nunatak group in Antarctica. Polar Biol. 10, 151-160.

Sømme, L. 1982: Supercooling and winter survival in terrestrial arthropods. Comp. Biochem. Physiol. 73A, 519-543.

Sømme, L. 1986a: New records of terrestrial arthropods from Dronning Maud Land, Antarctica. Polar Res. 4 n.s., 225229.

Sømme, L. 1986b: Fcology of Cryptopygus sverdrupi (Collembola) from Dronning Maud Land, Antarctica. Polar Biol. 6, 179-184. 
Sømme, L. \& Block, W. 1991: Adaptations to alpine and polar environments in insects and other terrestrial arthropods. Pp. 318-359 in Lee, R. E., Jr. \& Denlinger, D. L. (eds.): Insects at low temperature. Chapman \& Hall, New York, London.

Sømme, L. \& Zachariassen, K. E. 1981: Adaptations to low temperature in high altitude insects from Mount Kenya. Ecol. Entomol. 6, 199-204.

van der Laak, S. 1982: Physiological adaptation to low temperature in freeze-tolerant Phyllodecta laticollis beetles. Comp. Biochem. Physiol. 73A, 613-620.

Wallwork, J. A. 1967: Cryptostigmata (Oribatid mites). Pp.
105-122 in Gressitt, J. L. (ed.): Entomology of Antarctica. Antarctic Research Series 10. American Geophysical Union, Washington.

Winther, J, G. 1990: Glaciological and meteorological measurements in Dronning Maud Land. Norsk Polarinst. Medd. 113, 81-86.

Zachariassen, K. E. 1985: Physiology of cold tolerance in insects. Physiol. Rev. 65, 799-832.

Zachariassen, K. E. \& Husby, J. A. 1982: Stabilization of highly supercooled insects by thermal hysteresis antifreeze agents. Cryo-Letters 3, 316. 